\title{
Familial Cancer in Women from the Gomel Region of Belarus
}

G.M. Porubova and E.M. Ekimova

Institute of Genetics and Cytology, National Academy of Science, Akademicheskaya str. 27, 220072, Minsk, Belarus

\section{INTRODUCTION}

Breast cancer is the commonest malignancy among women in Belarus. During last 10 years the total incidence of breast cancer has doubled and a change in pathological features was observed. Registered incidence rates were increased in the age groups 30-39 and over 50 years [1].

The Chernobyl nuclear accident caused a unique radio-ecological situation on the territory of Belarus. More then 23\% of its territory was contaminated and more then 2 million people live under chronic exposure to low dose irradiation [2].

If we accept the concept of hormesis, there is no threshold dose below which there is risk of radiation-induced cancer. The incidence of any type of cancer may be increased after exposure to radiation, but the risks per centigray are not the same for all organs. Breast, thyroid and bone marrow appear to be the most radiosensitive tissues [3].

According to a "two-hit" model of dominantly inherited predisposition to cancer [4] and to the fact that any dose of radiation can induce cancer [5], it can be suggested that carrier of genes predisposing to breast cancer might be more radiosensitive [6]. However, there are no available data on the influence of low dose irradiation on inherited breast cancer. The clearing up of this question is very important because of the introduction of mammography to screening programmes for high-risk groups, e.g., hereditary breast cancer.

In 1990 we started work on familial breast cancer among the populations living in 3 regions of Belarus most affected by Chernobyl (Gomel, Mogilev and Brest regions). The total population of the 3 regions is 4.33 million.

\section{METHOD}

To obtain genetic information from breast cancer patients a special questionnaire was sent annually to those registered in Cancer Register from 1991 till 1997. About 40\% of completed questionnaires were returned.

\section{DISCUSSION}

2122 breast cancer patients were registered in Gomel region in 1991-1997. We sent only 1729 letters because we decided not to investigate those who had died and others who had problems with address (wrong address or its changing etc). 710 replies (41\%) were received with 323 "sporadic" cancers (only 1 breast cancer in the family) and 299 "familial" cancers (more then 1 case of cancer in the family) (Table 1).

Among families with more then 1 case of cancer there was 1 family with 9 cases of different cancers; 2 families with 8 cases; 2 families with 7 cases; 9 families with 6 cases; 14 families with 5 cases; 48 families with 4 cases; 81 families with 3 cases and 143 families with 2 cases of different cancers (Table 2). 
Table 1

\begin{tabular}{cccccc}
\hline Year & BC registered & L send & L returned & Sporadic BC & Familial BC \\
\hline 1991 & 240 & 213 & 95 & 47 & 30 \\
1992 & 281 & 248 & 94 & 43 & 41 \\
1993 & 239 & 209 & 86 & 31 & 43 \\
1994 & 264 & 230 & 97 & 48 & 40 \\
1995 & 389 & 259 & 99 & 49 & 41 \\
1996 & 403 & 271 & 115 & 49 & 48 \\
1997 & 306 & 299 & 124 & 56 & 46 \\
\hline
\end{tabular}

$\mathrm{BC}=$ breast cancer; $\mathrm{L}=$ letters

Table 2

\begin{tabular}{ccccccccc}
\hline Year & 2 cases & 3 cases & 4 cases & 5 cases & 6 cases & 7 cases & 8 cases & 9 cases \\
\hline 1991 & 11 & 12 & 5 & 3 & & & & \\
1992 & 14 & 11 & 8 & 4 & 3 & 1 & 1 & 1 \\
1993 & 24 & 11 & 5 & 1 & & & \\
1994 & 24 & 10 & 5 & & & & \\
1995 & 20 & 11 & 7 & & 3 & & \\
1996 & 26 & 17 & 9 & 5 & 1 & & \\
1997 & 24 & 9 & 9 & 1 & 2 & & & \\
\hline
\end{tabular}

Two families with site-specific breast cancer were found: four breast cancers in the first diagnosed at 41, 63, 55 and 58 years and 3 breast cancers diagnosed at 35, 54 and 51 years + uterine cancer diagnosed at 51 years.

\section{CONCLUSION}

We hope that comparative analysis of incidence rate of familial and sporadic breast cancer between population living on radiocontaminated territories and population living on so called "clean" territories can make it possible to clarify in future a question about the influence of additional irradiation on carriers of genes predisposing to breast cancer.

\section{References}

[1] Malignant neoplasms in Belarus 1988-1997. Belarussian Cancer Registry. Minsk (1998) p. 179.

[2] Belarus i Chernobyl - vtoroe decyatiletie. Sb. pod redactsiei Ministra po chrezvuchainum situatsiyam I.A. Kenika. Baranovichi (1998) p. 92.

[3] Boice, J.D. Cancer following medical irradiation. Cancer 47, (1981) 1080-1090.

[4] Knudson, A.G. Hereditary cancer: two hits revisited. J. Cancer Res. Clin. Oncol. 122, (1996) 135-140.

[5] Weber, M. (ed). Ionisierende Strahlen und Krebs. Berne: Ligue Suisse Contre le Cancer (1990).

[6] Swift, M. Ionizing radiation, breast cancer and ataxia-teleangiectasia. L. Nat. Cancer Inst. 866, (1994) 1571-1572. 


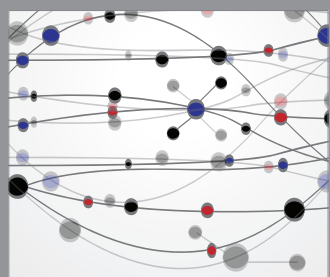

The Scientific World Journal
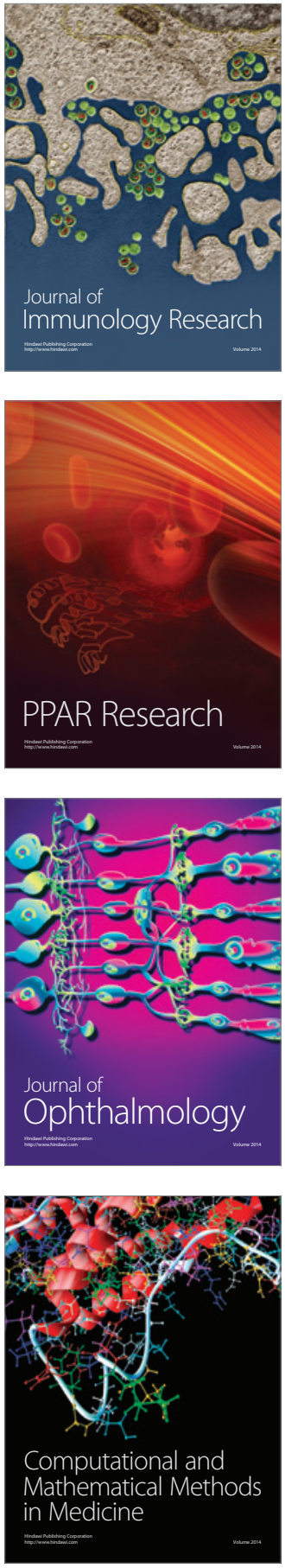

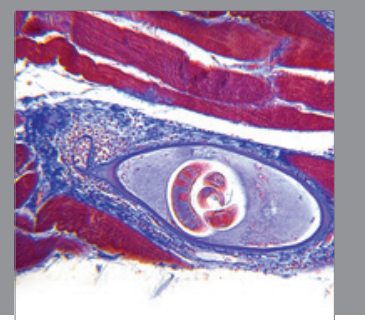

Gastroenterology

Research and Practice
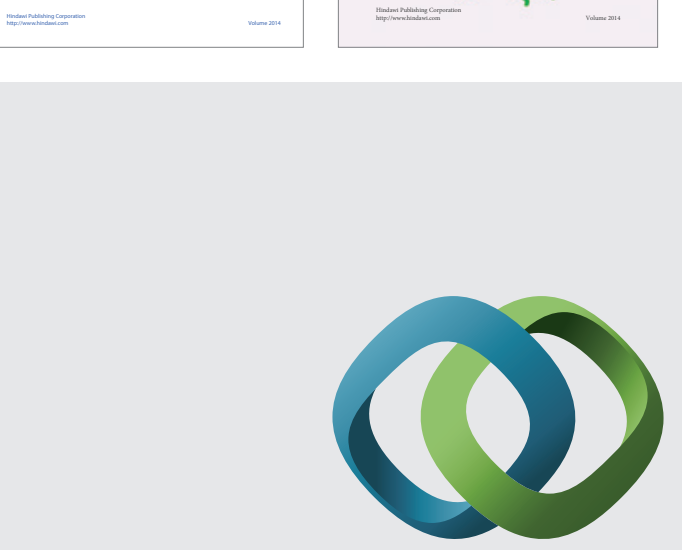

\section{Hindawi}

Submit your manuscripts at

http://www.hindawi.com
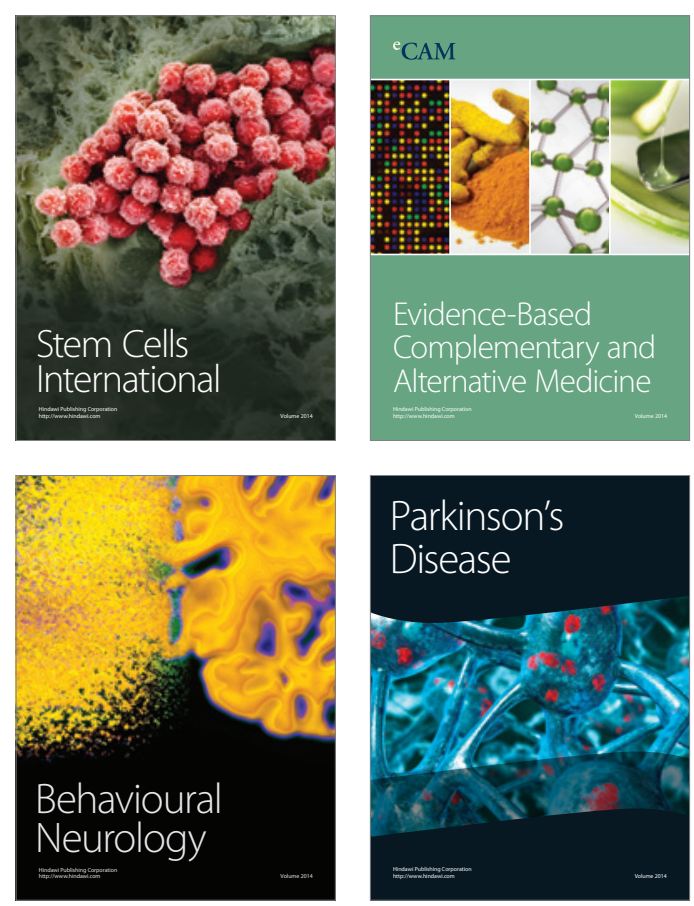

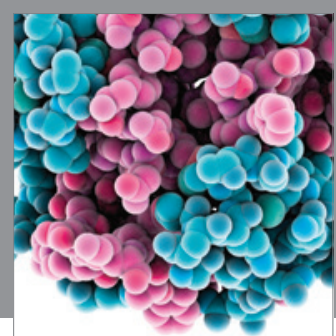

Journal of
Diabetes Research

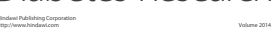

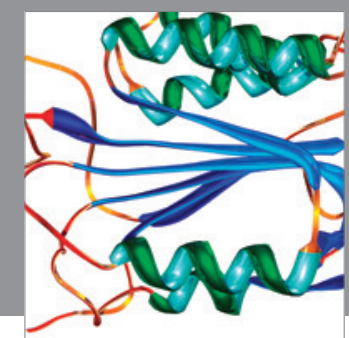

Disease Markers
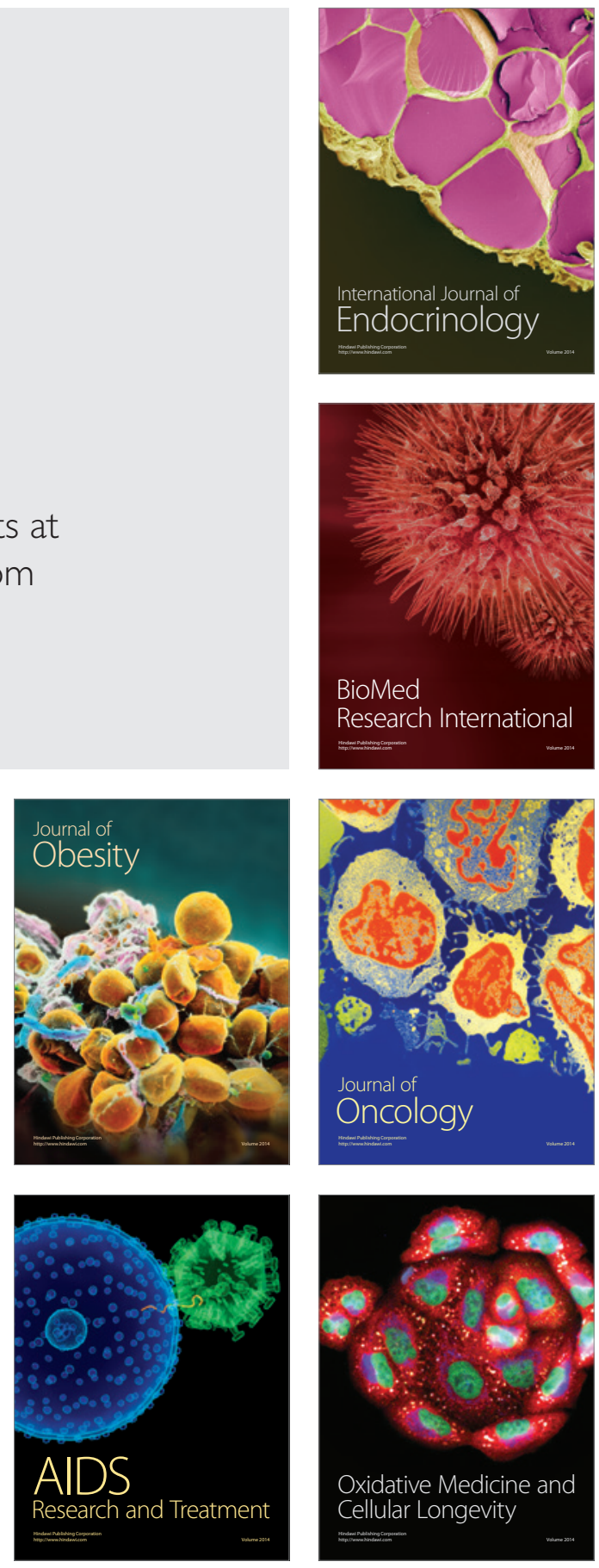